\title{
Se din egen tekst utenfra
}

Det er lett å se seg blind på sin egen tekst. Derfor kan korrektur og språkvask være nyttig.

\section{Forfatter}

John Ellefsen

Korrekturleser og språkvasker

Språk Teori Korrektur

Sykepleien Forskning 2019 14(52906)(e-52906)

DOI: https://doi.org/10.4220/sykepleienf.2012.0109

Kan man se sin egen tekst utenfra? Generelt må man svare: Bare til en viss grad, for ingen kan bedømme sitt eget språk objektivt. Dersom vi har skrevet en artikkel, for eksempel en sykepleiefaglig forskningsoppgave, kan det være at vi sender teksten til en kollega og ber om en faglig vurdering, og deretter til korrekturleser/språkvasker - som heller ikke er objektiv, men likevel kan gi nyttige innspill. Alle vurderer teksten ut fra sine egne kunnskaper og sitt eget skjønn.

I språket, som i livet for øvrig, er det nærliggende å tenke på utsagnet om at man ser splinten i sin brors øye, men ikke bjelken i sitt eget. Hvor ofte er man ikke dundrende uenige om hva som er rett og galt? Ikke desto mindre må vi erkjenne at en velformulert og noenlunde feilfri tekst er det som virker mest tillitsskapende, det vil si at leseren får tillit til forfatteren og leser det han eller hun har skrevet, med et åpent sinn. 


\section{Lettfattelig}

Jeg, som skriver denne teksten, har lest korrektur og utført språkvask på artikler med tema fra sykepleien. Jeg er blitt bedt om å dele mine erfaringer med leseren og komme med noen enkle språkråd. Det ble en utfordrende oppgave. Ved første gangs gjennomlesning av min egen tekst så jeg at jeg hadde begått samtlige feil som dem jeg her skal forsøke å advare mot. Så, kjære leser, ta frem rødblyanten, spiss den godt og se hva du finner av merkverdigheter i teksten her ...

En av grunnene til at vi både snakker og skriver så ulikt her i landet, er utvilsomt det norske språkets kompliserte historie med bakgrunn i vestnorsk, østnorsk og dansk. Ikke bare har vi bokmål og nynorsk, men også varianter av disse to. Og de utvikler seg stadig, noen vil mene for raskt.

Så hva kjennetegner et godt språk? Etter mitt skjønn først og fremst det at forfatterens intensjoner er lette å lese og oppfatte.

\section{Tvetydighet}

Med andre ord: unngå enhver utilsiktet tvetydighet. Det hender jeg sier noe bare for å dekke over det jeg egentlig har i tankene. For eksempel: Forfatteren er nå kommet godt opp i årene, men vi gleder oss allerede til å høre mer fra ham i årene som kommer.

Som kjent leser vi alle også mellom linjene. Og der er det lett å lese noe helt annet, nemlig at man nå ikke lenger tar det for gitt at denne forfatteren har mer å gi. Og mon tro hva leseren tenker om denne: Han ble høyt verdsatt, ingen tvil om det, men han var dessverre komplett umulig å snakke til ...

\section{I forhold til}


En helt annen form for tvetydighet, eller utydelighet, kan oppstå i forbindelse med den nye bruken av uttrykket i forhold til. Denne formuleringen er noe omstridt fordi den iblant kan virke upresis og noen ganger gi flere tolkningsmuligheter. Den opprinnelige betydningen er «sammenliknet med». Eksempel:

Gutten er høy i forhold til andre på hans alder.

Den nye betydningen skal nok være «når det gjelder». Eksempel: Han må ta stilling i forhold til problemet. Iblant er formuleringen også overflødig; foregående setning kunne like gjerne vært formulert slik: Han må ta stilling til problemet. Og hva betyr: Hun hadde store krav i forhold til ham? Betyr det: Hun hadde store krav til ham, Hun hadde store krav til forholdet til ham, eller Hun hadde større krav enn han hadde?

Noen eksempler fra tv-nyhetene: Det var dårlig gjort av denne fotballspilleren i forhold til denne klubben. Låter det så mye bedre enn simpelthen: Det var dårlig gjort av ham mot denne klubben? Og om en mulig streik: De får problemer i forhold til skolen. Er det så mye flottere enn bare: De får problemer med skolen? Og: Vi trenger ordentlige regler i forhold til de våpnene vi produserer. Er det bedre enn: Vi trenger ordentlige regler for de våpnene vi produserer?

I mange tilfeller er det nok, og mer presist, med en preposisjon: mot, for, til, på, overfor. Det kan også være bedre å skrive i forbindelse med, i forholdet til, $i$ henhold til, hva angår eller hva gjelder.

\section{Fokus}

Et annet ord som også er blitt revet løs fra sin opprinnelse, er fokus, som betyr «brennpunkt». Å fokusere i overført betydning er å konsentrere oppmerksomheten mot ett punkt eller én sak. Nå brukes det $\mathrm{i}$ alle mulige og umulige sammenhenger, like upresist som $i$ forhold til. 
Strengt tatt kan man hverken utvide eller sette fokus.

Det heter å utvide oppmerksomheten eller å samle den! $\AA$ skrive at man har et bredt, sterkt, høyt eller vidt hovedfokus - glem det!

\section{Bestemt form}

Substantiver i bestemt form entall og flertall er også verdt å se på i forbindelse med tekstens tydelighet. Ta for eksempel substantivene en pasient, en forsker. Etter at man har definert hvilke pasienter og hvilke forskere som artikkelen omtaler - for eksempel pasientene som deltok i undersøkelsen, forskerne ved høyskolen - må man gjerne benytte bestemt form og omtale dem som pasientene, forskerne.

Ikke slik (i genitiv): Vi ser at pasienters og forskeres opplevelse av undersøkelsen er vidt forskjellig. Det virker noe fremmedgjort! Leseren vet jo hvem disse er: Vi ser at pasientenes og forskernes opplevelser av undersøkelsen er vidt forskjellige. Ved bruk av bestemt form blir språket mer dagligdags og dermed lettere å lese og å oppfatte.

\section{Lange setninger}

Vil man være tydelig, er det enda viktigere å styre unna lange setninger med flere innskutte ledd. Går setningen over to-tre hele linjer, er det grunn til å bli kritisk. Kan den deles opp i flere små setninger, simpelthen ved å si én ting om gangen? Ja, skulle det ikke være nok å si en ting én gang?

Ganske ofte ser man at forfatteren forteller det samme budskapet flere ganger, bare i en litt annen form - som om han eller hun er redd for ikke å bli forstått ved første forsøk.

\section{Telegramstil}


På den andre siden er den litt knappe telegramstilen, som mange forfattere kanskje tilstreber, heller ikke alltid forenlig med et flytende, lett tilgjengelig språk. Riktignok heter det: Skriv kort og godt, men iblant kan man med fordel beholde tilsynelatende overflødige, ofte små, ord som hører til i teksten. Disse vil lette forståelsen, især når setningene blir lange:

- Talen mannen holdt $>$ Talen som mannen holdt.

- Stedet hjelpen finnes > Stedet hvor hjelpen finnes Stedet der hjelpen finnes.

- Han umuliggjør å hente flere > Han gjør det umulig å hente flere.

- Man må møte utfordringene som kommer > Man må møte de utfordringene som kommer.

Tydelighet er bra, men selvfølgeligheter er noe annet. Hvis det du forteller, er svært selvfølgelig, tenk over hvorfor du i det hele tatt skriver setningen. Eksempler:

- Sykepleierstudentene hadde eksamen i slutten av studieåret.

- Vi observerte at sykepleierne kom til kveldsvakt.

- Pasientene hoppet i vannet og ble våte.

Fortell oss heller noe vi kanskje ikke visste fra før:

- Sykepleierstudentene hadde eksamen i slutten av studieåret, men måtte levere en selvvalgt oppgave før jul.

- Vi observerte at sykepleierne ofte kom for sent til kveldsvakt.

- Pasientene hoppet motvillig i vannet og ble gjennomvåte tross redningsdraktene.

\section{Tegnsetting}

Tegnsetting har også med tydelighet å gjøre ved at den «rydder opp» i teksten og dermed fremhever meningen eller budskapet. 
Først noen ord om anførselstegn. De brukes naturligvis mest for å sitere noen. Men anførselstegn er også anvendelig når man vil «låne» et ord eller uttrykk som ikke er vanlig i den aktuelle sammenhengen.

Men bruk dem ikke i utide, slik jeg nettopp gjorde her, to ganger. Hvis jeg mener å rydde opp og å låne, så bør jeg skrive det uten «å unnskylde meg», - eh, uten å unnskylde meg! Det vil si uten anførselstegn!

Så litt om komma. Hva skal vi egentlig med dette tegnet? Jo, vi skal skille de forskjellige, meningsbærende setningsdelene fra hverandre for å markere hva som henger sammen med hva - og hva som bør holdes fra hverandre. Ta for eksempel setningen som kommer i siste avsnitt: «Gjennom det som i dag heter Språkrådet, har staten forsøkt å styre språkutviklingen, med vekslende hell.» Ta bort det siste kommaet, og det står at staten har forsøkt å mislykkes!

\section{三 «Disse kommareglene er kanskje dem vi oftest synder mot.»}

Sett komma mellom to hovedsetninger. Eksempel:

Han kommer nå, og han vil hjelpe oss. Sett komma mellom en bisetning og en hovedsetning når bisetningen kommer først. Eksempel: Hvis du kommer først, kan du gjerne hjelpe oss.

Har vi en innskutt relativ bisetning, skal den avsluttes med komma. Eksempel: Han som står der borte og snakker med sjefen, vil hjelpe oss. Hvis innholdet i den innskutte bisetningen ikke er nødvendig for hovedsetningen, skal det også settes komma før bisetningen. Eksempel: Han, som gjerne gikk med rød jakke til daglig, var ofte til stor hjelp for oss. 
Det samme gjelder dersom en bisetning kommer til slutt og den ikke er nødvendig for det som sies forut: Vi fikk ofte god hjelp av denne mannen, som gjerne kom med toget om morgenen. Hvis det derimot er et poeng at han kom tidlig om morgenen: Vi fikk god hjelp av denne mannen som kom så tidlig om morgenen.

Disse kommareglene er kanskje dem vi oftest synder mot. Vi glemmer dem - og strør litt tilfeldig om oss med kommaer bare for å indikere en pause, for å trekke pusten. Nå vel, noen ganger kan også det forsvares.

\section{Aktiv eller passiv}

Mange fag- og forskningsartikler inneholder en god del passive setningskonstruksjoner som med fordel kunne vært skrevet i aktiv.

- Eksempel på aktiv setning: Sykepleieren delte ut medisiner. Subjektet utfører handlingen.

- Eksempel på passiv setning: Medisinene blir utdelt av sykepleieren. Subjektet, medisinene, deler ikke ut - de blir utdelt. Verbformene er passive, de lages med hjelpeverbene å bli eller å vcre, eller ved å føye -s til verbet: Medisinene deles ut av sykepleieren.

Ta siste avsnitt over: Disse kommareglene er kanskje dem vi oftest synder mot. Vi glemmer dem - og strør litt tilfeldig om oss med kommaer bare for å indikere en pause, for å trekke pusten.

Jeg skriver det om i passiv: Det blir ofte syndet mot disse reglene. Reglene glemmes, og kommaer blir strødd ut litt tilfeldig. Det blir satt komma for å indikere en pause, for å trekke pusten.

\section{三 «Bruk passiv bare der det gjør setningen tydeligere og mer informativ.»}


Det ble neppe en bedre tekst av det! Det kan se ut som et forsøk på å holde subjektet tilbake, vi får ikke vite hvem det gjelder: forfatteren, vi, man ... Men som det også sto: Noen ganger kan det forsvares. Moralen blir: Bruk passiv bare der det gjør setningen tydeligere og mer informativ.

\section{Fint språk ...}

Hva er et fint språk? Konservativt riksmål? Moderat bokmål? Radikalt bokmål? Etter mitt skjønn er et godt språk, som før nevnt, et språk som er lett å forstå. Et klart språk. Distinkt. Et språk som kan brukes i enhver forsamling, til hverdags og fest, i dagligtalen så vel som i det skriftlige, i vitenskapen, kunsten og religionen.

I etterkrigstidens språkstrid sto kampen spesielt mellom radikalt og moderat bokmål, for eksempel fram/frem, boka/boken. I dag ser det ut til at toleransen er større på begge sider, og vi finner begge formene i Bokmålsordboka fra Språkrådet og Universitetet i Bergen: ordbok.uib.no. For øvrig anbefaler jeg også Det Norske Akademis ordbok: naob.no.

\section{Moderat eller radikal}

Når man skriver en artikkel, er det selvsagt lov å blande de moderate og radikale formene, men de fleste vil nok mene at det er best å holde seg til én form av ett og samme ord i én og samme artikkel - altså enten fram eller frem, boka eller boken.

Men hva om man bruker fram og boken i samme tekst? Kanskje det! Frem og boka? Kanskje ikke? På NRK sa de nylig: «Vi viser Venus som passerer mellom solen og jorda.» Hmm! Og hva med: «Nyhetene klokken tjueen»? Vel, det låter i det minste langt bedre i dag enn for bare tyve år siden. Mens Word setter sikksakkstrek under tyve! 
Så kan man videre spørre seg, blir språket bedre ved at vi ikke skiller mellom enda og ennå, og at vi beveger oss bort fra objektsformene ham og dem?

På Vestlandet har de ikke sagt dem på lang tid, så vidt jeg vet. Men de lever i beste velgående og snakker fortsatt sammen. Men kanskje vi skulle beholde objektsformen dem i det skriftlige? Ja, hva skriver vi dersom folk flest uttaler skjønn når de mener kjønn? Etter mitt skjønn ... er det grunn til å tenke seg om.

\section{Hva er godt språk?}

Gjennom det som i dag heter Språkrådet, har staten forsøkt å styre språkutviklingen, med vekslende hell. Det er fortsatt ikke konsensus i folket om hva som er godt norsk språk. Du og jeg, forfattere og skribenter i statlig eller privat virksomhet, har - mer eller mindre gått våre egne veier etter at vi forlot den obligatoriske skolegangen.

Med andre ord: Vi som skriver, er alle med på å påvirke utviklingen av det norske skriftspråket! Språket eier vi sammen. Like fullt er det et svært personlig anliggende. Ingen har patent på det! 